ISSN 0206-5657. Вісник Львівського університету. Серія біологічна. 2018. Випуск 79. С. 29-37 Visnyk of the Lviv University. Series Biology. 2018. Issue 79. P. 29-37

УДК $581.1+582.54$

\title{
ISOENZYME VARIATION AND GENETIC AFFINITIES AMONG FIVE FESTUCA SPECIES OF SECTION AULAXYPER DUMORT.
}

\author{
G. Angelov ${ }^{1 *}$, I. Bednarska ${ }^{2}$ \\ ${ }^{I}$ Institute of Biodiversity and Ecosystem Research Bulgarian Academy of Sciences \\ 23, Acad. G. Bonchev St., 1113 Sofia, Bulgaria \\ *e-mail: jorkata_1953@mail.bg \\ ${ }^{2}$ Institute of Ecology of the Carpathians, NAS of Ukraine \\ 4, Kozelnytska St., Lviv 79026, Ukraine \\ e-mail:ibednarska@ukr.net
}

Despite a considerable number of taxonomical and biosystematic studies of genus Festuca L. in Europe, there are few papers discussing phylogeny and systematic of genus Festuca as well the evolution of its different groups. The most important among them are the studies of N. Tzvelev, who proposed three sections within type subgenus Festuca: Variae Hack., Aulaxyper Dumort. and Festuca. There are many studies on species belonging to section Festuca, including chemosystematic ones, but the species of section Aulaxyper are rather neglected. For this reason we choose F. rubra L., F. nigrescens Lam., F. picturata Pils., F. amethystina L. and F. heterophylla Lam., which belong to section Aulaxyper. The aim of the study was to examine the isoenzyme variation and to evaluate the genetic affinities among the above-listed species of genus Festuca.

Ten natural Bulgarian populations were examined. The isoforms of enzymes glutamate-oxaloacetate transaminase, malate dehydrogenase, glutamate dehydrogenase, isocitrate dehydrogenase and 6-phosphogluconate dehydrogenase were resolved by polyacrylamide gel electrophoresis. Based on mean allelic frequencies/locus/taxon, genetic identities (I) values for all pair-wise comparisons among the studied species were calculated.

The group of $F$. rubra s.l. is more primitive compared to $F$. ovina s.l. and has sheaths closed nearly to the mouth while the sheaths of species of section Festuca are closed to the base. Festuca amethystina occupies an intermediate position as its sheaths are closed for $1 / 3-1 / 2$ of their length. This character indicates for its specific position within section Aulaxyper and isolates it from the rest taxa of the group. Our results confirmed its peculiar position within section Aulaxyper. Festuca heterophylla at the same time includes both primitive traits which are specific for the ancient species of genus Festuca, and the number of highly-specialized characters. The obtained molecular data confirm a peculiar position of F. heterophylla within genus Festuca. On the contrary, the closely related to F. rubra polyploids, namely $F$. nigrescens and $F$. picturata should be considered as more recent "new" species. Festuca amethystina showed the greatest divergence and should be considered also as an ancient species.

Keywords: Festuca, isoenzymes, variation, systematic relationships

\section{Introduction}

Festuca (fescue) is a genus of flowering plants belonging to the grass family, Poaceae (subfamily Pooideae). Because of its complicated taxonomy, it is not clear how many true species belong to the genus, but estimates range from over 400 to over 500. Since Hackel's Monographia Festucarum Europaearum [16] and the studies of many festucologists from the first several decades of 20-th century, Markgraf-Dannenberg [20] proposed a contemporary treatment of this genus in Flora Europaea. Since Flora Europaeaa, series of taxonomical and biosystematic studies on critical groups of Festuca were carried out [9-11, 26-28].

(C) Angelov G., Bednarska I., 2018 
However there are few papers discussing phylogeny and systematic of genus Festuca as well as the evolution of its different groups. Most important among them are the studies of $\mathrm{N}$. Tzvelev [29, 30]. His main approach is comparative analysis of morphological and anatomical traits (primitive/advanced) of different taxa within Festuca. Recently N. Tsvelev [31] proposed three sections: Variae Hack., Aulaxyper Dumort. and Festuca within type subgenus Festuca. There are many studies on species belonging to section Festuca, including chemosystematic ones $[1-3,15]$ but the species of section Aulaxyper are rather neglected. For this reason we choose species belonging to section Aulaxyper (type F. rubra) which is among the most primitive sections of thin-leaves fescues. These species are characterized with extravaginal shoots, often flat leaves, specific anatomy of vegetative leaves (multifaceted leaf cross-sections, more than 3 sclerenchyma strands, deep grooves between ribs on adaxial surface), in certain species ovary hairy at apex, sheaths closed to the mouth. For comparison, the evolutionary more advanced section Festuca is characterized with hairless ovary, lack of extravaginal shoots, very thin leaves (sclerenchyma as subepidermal layer or 3 strands), with less prominent ribs on adaxial surface, as well sheaths closed to no more than $1 / 3$.

The present study includes F. rubra L., F. nigrescens Lam. (syn. F. rubra subsp. fallax (Thuill.) Nym.), F. picturata Pils. (syn. F. violacea subsp. picta (Kit.) Hegi), F. amethystina L. and F. heterophylla Lam. They belong to the section Aulaxyper Dumort. of the type subgenus Festuca. The comparative characteristics of the species [32,33] are given in Table 1.

Table 1

Comparative characteristics of the species [32, 33]

\begin{tabular}{|c|c|c|c|}
\hline Species & Life form & Non-flowering shoots & Flowering shoots \\
\hline F. rubra & $\begin{array}{l}\text { Laxly caespitose, } \\
\text { with rhizomes, } \\
\text { extravaginal shoots }\end{array}$ & $\begin{array}{l}(0,5-) 0,6-1,2 \mathrm{~mm} \text {, flat; } \\
\text { sheaths closed nearly to } \\
\text { the mouth }\end{array}$ & $\begin{array}{c}30-80 \mathrm{~cm} \text {; under a panicle glabrous; } \\
\text { ovary glabrous, rarely with solitary hairs } \\
2 \mathrm{n}=14,28,42,56\end{array}$ \\
\hline F. nigrescens & $\begin{array}{l}\text { Densely caespitose, } \\
\text { most of shoots } \\
\text { intravaginal }\end{array}$ & $\begin{array}{c}0,4-0,7 \mathrm{~mm} \text {, flat; } \\
\text { sheaths closed to the } \\
\text { mouth }\end{array}$ & $\begin{array}{c}30-80 \mathrm{~cm} \text {, under a panicle glabrous; } \\
\text { ovary glabrous } \\
2 \mathrm{n}=42\end{array}$ \\
\hline F. picturata & $\begin{array}{l}\text { Densely caespitose, } \\
\text { all or most of } \\
\text { shoots extravaginal }\end{array}$ & $\begin{array}{l}(0,4-) 0,5-0,75 \mathrm{~mm}, \text { flat; } \\
\text { sheaths closed nearly to } \\
\text { the mouth }\end{array}$ & $\begin{array}{l}(20-) 30-40(-50) \text { cM, under a panicle } \\
\text { densely shortly hairy; } \\
\text { ovary usually sparsely hairy at apex } \\
\qquad 2 \mathrm{n}=14\end{array}$ \\
\hline F. amethystina & $\begin{array}{c}\text { Densely caespitose, } \\
\text { extravaginal shoots } \\
\text { from few (subsp. } \\
\text { amethystina) to } \\
\text { numerous (subsp. } \\
\text { orientalis) }\end{array}$ & $\begin{array}{c}0,4-0,6 \mathrm{~mm} \text {, glabrous or } \\
\text { nearly glabrous, pruinose; } \\
\text { sheaths purple-violet, } \\
\text { closed for } 1 / 3-1 / 2 \text { of their } \\
\text { length }\end{array}$ & $\begin{array}{l}30-60 \mathrm{~cm} \text {; under a panicle glabrous to } \\
\text { slightly scabrid; } \\
\text { ovary glabrous or subglabrous } \\
2 \mathrm{n}=28\end{array}$ \\
\hline F. heterophylla & $\begin{array}{l}\text { Densely caespitose, } \\
\text { most of shoots } \\
\text { intravaginal }\end{array}$ & $\begin{array}{l}(0,3-) 0,4-0,6 \mathrm{~mm} \text {, scabrid; } \\
\text { sheaths closed, glabrous } \\
\text { or slightly scabrid }\end{array}$ & $\begin{array}{c}(50-) 60-120 \mathrm{~cm} \text {, cauline leaves } 2-3 \mathrm{~mm} \\
\text { wide; } \\
\text { ovary densely hairy at apex } \\
2 \mathrm{n}=28,42\end{array}$ \\
\hline
\end{tabular}

Within the group F. rubra is the most polymorphic and widely spread. This is a laxly caespitose species, usually with more or less long rhizomes, distributed almost throughout Europe. The rest of species have combined type of reproduction with different combinations of intra/extravaginal shoots. A common feature of these species is also their origin and distribution is related to mountain systems of Europe. For example, F. nigrescens is a densely caespitose species, which firstly was occurring in high mountain meadows. At present it is used as a component in seed mixtures for artificial meadows. It widened its distribution but made difficult the distinction between F. nigrescens and F. rubra. Its distribution range encompasses S., W. \& C. 
Europe, reaching to S. Sweden. Festuca picturata is rather densely caespitose plant. It is usually calcicole, occurring in E. Alps; Carpathians and the mountains of Bulgaria. Festuca amethystina and $F$. heterophylla are a densely caespitose species. The first one occupies dry places in Alps, C. Europe and Balkan peninsula, while the second species prefers habitats mainly in woods and it is distributed from S. England and Poland southwards to N.W.Spain and Greece.

Isoenzymes are valuable genetic markers. Their most significant advantage is the simple genetic basis of their polymorphism. Being proteins, they can directly reflect alterations in the genome. Electrophoretic methods for isoenzyme analysis testified their value to resolving systematic and evolutionary problems on species and subspecies level $[6,14]$. In the last two decades several isoenzyme studies of subarctic/arctic [1-3, 15] and temperate zone fescues [19] were conducted in attempt to investigate species delimitation based on isoenzyme markers.

The aim of the study was to examine the isoenzyme variation and to evaluate the genetic affinities among the above-listed species of genus Festuca.

\section{Materials and Methods}

Living plants (25-30 individuals/population) belonging to 10 natural Bulgarian populations were examined (Table 2). Vouchers are deposited at the Herbarium of Institute of Biodiversity and Ecosystem Research in Sofia (SOM).

Table 2

\begin{tabular}{|l|l|}
\multicolumn{2}{c}{ Species and populations' localities } \\
\hline Species & \multicolumn{1}{c|}{ Populations' localities } \\
F. rubra nigrescens & $\begin{array}{l}\text { Rila Mt., in the vicinity of Vada chalet } \\
\text { Stara Planina Mt., around Chumerna charcoal mine } \\
\text { Rila Mt., Parangalitsa reserve } \\
\text { Fhodopes Mt., Kupena reserve } \\
\text { Ficturata }\end{array}$ \\
$\begin{array}{l}\text { Vitosha Mt., around Aleko chalet, Platoto } \\
\text { Rila Mt., in the vicinity of Dodov vrah peak }\end{array}$ \\
F. heterophylla & $\begin{array}{l}\text { Vitosha region, around Iskar dam } \\
\text { Rila Mt., in the vicinity of Treshtenik chalet } \\
\text { Rila Mt., around Gorna Caditsa peak } \\
\text { Rila Mt., along Bistritsa river, 2-3 km westwards Ivan Vazov chalet }\end{array}$ \\
\hline
\end{tabular}

The isoforms of enzymes glutamate-oxaloacetate transaminase (GOT, EC 2.6.1.1), malate dehydrogenase (MDH, EC 1.1.1.37), glutamate dehydrogenase (GDH, EC 1.4.1.2), isocitrate dehydrogenase (IDH, EC 1.1.1.6) and 6-phosphogluconate dehydrogenase (6PGDH, EC 1.1.1.44) were resolved by polyacrylamide gel electrophoresis. Leaf samples $(0.1 \mathrm{~g})$ were ground in $0.3 \mathrm{ml}$ extraction buffer $(0.01 \mathrm{M}$ Tris, $0.08 \mathrm{M}$ glycine, $0.005 \mathrm{M}$ cysteine and $20 \%$ sucrose) at $\mathrm{pH} 8.3$. Ion-exchange resin Dowex 1 x $8(0.4 \mathrm{~g} / 1 \mathrm{~g}$ fresh tissue) was added to the extraction buffer to eliminate polyphenols. Homogenates were centrifuged at $10000 \mathrm{rpm}$ for $10 \mathrm{~min}$. The supernatant was used as a source of enzymes. The enzymes were resolved on $7.5 \%$ separating gel (3\% stacking gel) polyacrylamide slabs using the electrophoretic system of B. Davis [7]. The length of the separating gel was $7 \mathrm{~cm}$ and stacking gels were $2 \mathrm{~cm}$ long. Electrophoresis was conducted at $200 \mathrm{~V}$ until the indicator dye bromophenol blue reached the gel end. Staining of gels followed procedures described by C. Shaw \& R. Prasad [25] for MDH and GDH, J. Przybylska et al. [23] for GOT, N. Henderson [17] for 6PGDH and F. Yeh \& D. O'Malley [35] for IDH.

Zones of enzyme activity that varied independently of other such zones were considered to be coded by single gene loci. According to D. Crawford [6], different genes (loci) coding the same enzymes (isoenzymes) were designated according to the relative mobility of the enzymes they specify. That is, the gene coding the most anodal isoforms was designated by (1), the next most anodal one, (2), etc. In each locus the allele coding the fastest isoform was designated by 
(a), the next fastest by (b), and so on. Based on mean allelic frequencies/locus/taxon, genetic identities (I) were calculated [21].

Genetic affinities among the studied Festuca species were presented graphically as a dendrogram produced from Nei's identities matrix using STATISTICA 7.0. An index of group affinity (GA) was calculated for each taxon as a sum of its I values.

\section{Results and Discussion}

Genetic interpretation of enzyme banding patterns was based on two lines of evidence the known subunit structure of enzymes and their segregation patterns within species. Three gene loci and dimeric subunit structure are supposed for GOT in Secale $[8,22]$ and Triticum $[18,24]$. The enzymes MDH and 6-PGDH are dimers coded by three genes in maize and Secale [8, 22]. Two gene loci and dimeric subunit structure was proposed for IDH in barley [5].

The patterns of variation observed in the studied species of genus Festuca conform to the above-mentioned genetic models. The studied populations of each taxon were electrophoretically similar. Hence, the data for a taxon were pooled and mean frequencies were calculated. Mean allelic frequencies in the studied species are presented in Table 3. Totally, four enzymes, putatively coded by eleven gene loci, namely, 6-PGDH 1, 2, 3, GOT 1, 2, 3, MDH 1, 2, 3 and IDH 1, 2 were scored. Most of alleles were shared by all studied species - an indication for their close relationships. Excepting $F$. heterophylla, the studied species were monomorphically fixed for allele $\mathrm{c}$ of gene locus 6-PGDH 2. The species F. rubra, F. nigrescens, F. picturata were invariant for allele $\mathrm{c}$ of gene locus 6-PGDH 3, while $F$. amethystina and $F$. heterophylla were fixed for alleles a and b, respectively. Similarly, F. rubra, F. nigrescens , F. picturata were monomorphic for allele a of locus GOT 1. Excepting F. heterophylla, the examined species were monomorphically fixed for allele a of gene locus MDH 1. All studied species but $F$. heterophylla were invariant for allele a of MDH 3. Excluding F. amethystina, all species were fixed for allele $\mathrm{b}$ of locus IDH 1.The former was invariant for allele a. The same pattern was observed in respect to locus IDH 2.

Table 3

Mean allele frequencies in the studied species of genus Festuca

\begin{tabular}{|c|c|c|c|c|c|c|}
\hline Locus & Alelle & F.rubra & F. nigrescens & F. picturata & F. amethystina & F. heterophylla \\
\hline \multirow[t]{2}{*}{ 6PGDH 1} & $\mathrm{a}$ & 0.42 & 0.25 & 0.50 & 1.00 & 1.00 \\
\hline & $\mathrm{b}$ & 0.58 & 0.75 & 0.50 & 0.00 & 0.00 \\
\hline \multirow[t]{3}{*}{ 6PGDH 2} & $\mathrm{a}$ & 0.00 & 0.00 & 0.00 & 0.00 & 0.00 \\
\hline & $\mathrm{b}$ & 0.00 & 0.00 & 0.00 & 0.00 & 1.00 \\
\hline & c & 1.00 & 1.00 & 1.00 & 1.00 & 0.00 \\
\hline \multirow[t]{3}{*}{ 6PGDH 3} & $\mathrm{a}$ & 0.00 & 0.00 & 0.00 & 1.00 & 0.00 \\
\hline & $\mathrm{b}$ & 0.00 & 0.00 & 0.00 & 0.00 & 1.00 \\
\hline & c & 1.00 & 1.00 & 1.00 & 0.00 & 0.00 \\
\hline \multirow[t]{2}{*}{ GOT 1} & $\mathrm{a}$ & 1.00 & 1.00 & 1.00 & 0.20 & 0.84 \\
\hline & $\mathrm{b}$ & 0.00 & 0.00 & 0.00 & 0.80 & 0.16 \\
\hline \multirow[t]{2}{*}{ GOT 2} & $\mathrm{a}$ & 0.65 & 0.46 & 0.68 & 0.20 & 0.16 \\
\hline & $\mathrm{b}$ & 0.35 & 0.54 & 0.32 & 0.80 & 0.84 \\
\hline \multirow[t]{3}{*}{ GOT 3} & $\mathrm{a}$ & 1.00 & 1.00 & 0.47 & 0.00 & 0.00 \\
\hline & $\mathrm{b}$ & 0.00 & 0.00 & 0.53 & 0.42 & 1.00 \\
\hline & $\mathrm{c}$ & 0.00 & 0.00 & 0.00 & 0.58 & 0.00 \\
\hline \multirow[t]{2}{*}{ MDH 1} & $\mathrm{a}$ & 1.00 & 0.97 & 1.00 & 1.00 & 1.00 \\
\hline & b & 0.00 & 0.03 & 0.00 & 0.00 & 0.00 \\
\hline \multirow[t]{2}{*}{ MDH 2} & $\mathrm{a}$ & 0.63 & 0.33 & 0.73 & 0.43 & 0.59 \\
\hline & $\mathrm{b}$ & 0.37 & 0.67 & 0.27 & 0.57 & 0.41 \\
\hline \multirow[t]{2}{*}{ MDH 3} & $\mathrm{a}$ & 1.00 & 1.00 & 1.00 & 1.00 & 0.50 \\
\hline & $\mathrm{b}$ & 0.00 & 0.00 & 0.00 & 0.00 & 0.50 \\
\hline \multirow[t]{2}{*}{ IDH 1} & $\mathrm{a}$ & 0.00 & 0.00 & 0.00 & 1.00 & 0.00 \\
\hline & b & 1.00 & 1.00 & 1.00 & 0.00 & 1.00 \\
\hline \multirow[t]{2}{*}{ IDH 2} & $\mathrm{a}$ & 0.00 & 0.00 & 0.00 & 1.00 & 0.00 \\
\hline & $\mathrm{b}$ & 1.00 & 1.00 & 1.00 & 0.00 & 1.00 \\
\hline
\end{tabular}


Genetic identities values for all pair-wise comparisons among the studied species are given in Table 4. The values of coefficient I varied from 0.98 (F. rubra vs. F. nigrescens) to 0.40 when $F$. heterophylla was contrasted to $F$. amethystina. The species $F$. rubra, F. nigrescens, $F$. picturata were genetically tightly related, while but $F$. heterophylla demonstrated isolation within the group. Festuca amethystina was the most distant taxon (Fig 1). Index of group affinity contributed further to revealing the relationships within the examined group of genus Festuca. Lower values of index GA mean greater distance for a given taxon, and vice versa, higher values indicate a closer affinity within the group. The values of index GA for F. rubra and F. picturata (3.10) as well for F. picturata (3.01) are an indication for their close affinity within the studied group. F. heterophylla $(\mathrm{GA}=2.30)$ was relatively distant while $F$. amethystina $(\mathrm{GA}=1.93)$ proved to be the most isolated within the group. In short, the examined species could be arranged by their decreasing affinity and increasing genetic divergence as follows: F. rubra, F. nigrescens, F. picturata, F. heterophylla, F. amethystina.

Table 4

Genetic identities (I) for all pair-wise comparisons among the studied species of genus Festuca

\begin{tabular}{|c|c|c|c|c|c|c|}
\hline \multirow{2}{*}{\multicolumn{2}{|c|}{ Species }} & \multicolumn{5}{|c|}{ Genetic identity (I) } \\
\hline & & 1 & 2 & 3 & 4 & 5 \\
\hline 1 & F. rubra & 1.00 & 0.98 & 0.97 & 0.53 & 0.62 \\
\hline 2 & F. nigrescens & 0.98 & 1.00 & 0.94 & 0.49 & 0.6 \\
\hline 3 & F. picturata & 0.97 & 0.94 & 1.00 & 0.51 & 0.68 \\
\hline 4 & F. amethystina & 0.53 & 0.49 & 0.51 & 1.00 & 0.4 \\
\hline 5 & F. heterophylla & 0.62 & 0.60 & 0.68 & 0.40 & 1.00 \\
\hline
\end{tabular}

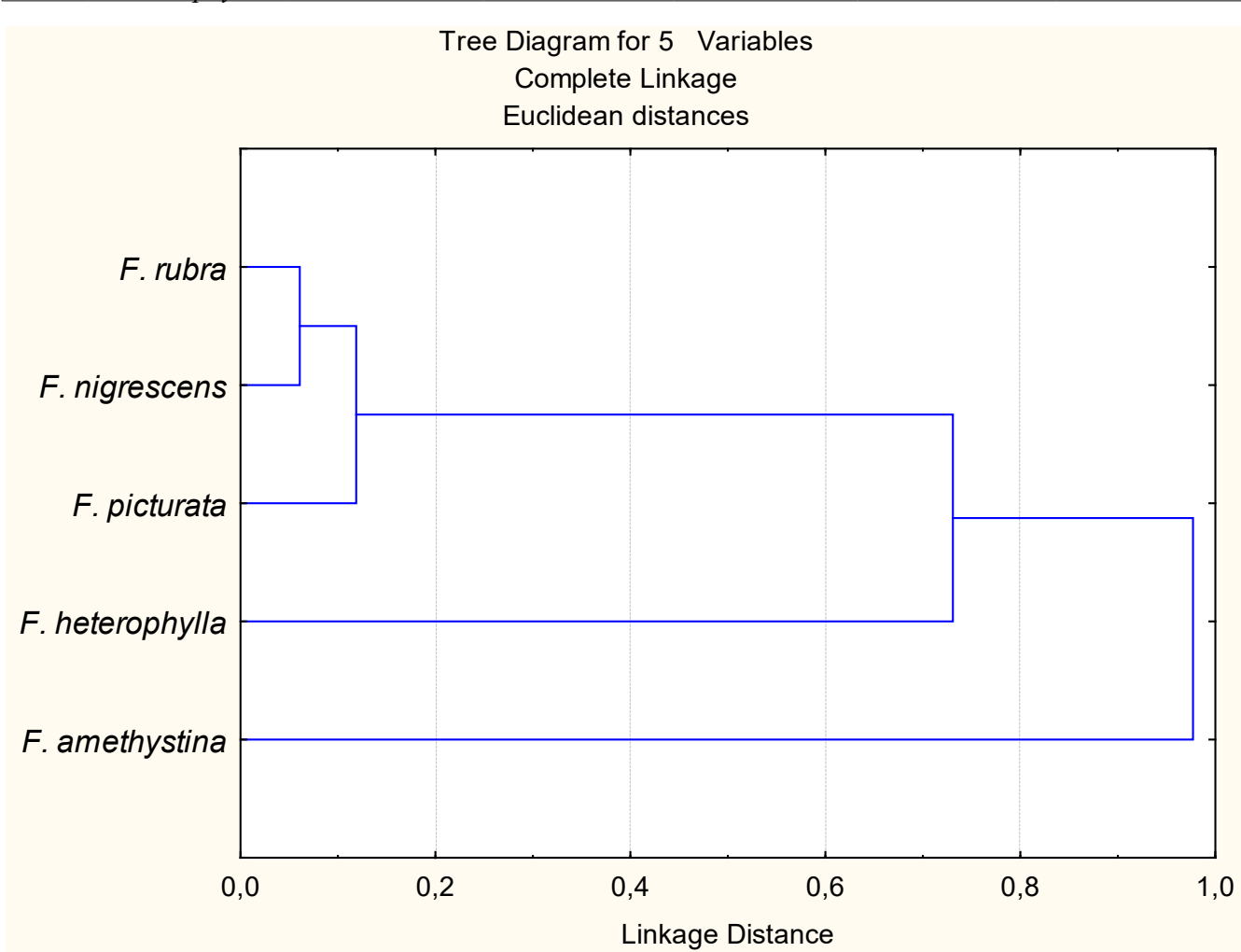

Fig. 1. The dendrogram of Cluster analysis for studied species of genus Festuca based on I coefficient (Genetic identities, Tabl. 4) 
The results of the study afforded an opportunity to shed light on the hypothetical evolution of section Festuca. Before discussing the topic, some considerations should be taken into account. First, analyzing progenitor-derivative species' pair as an example of rapid speciation, L. Gottlieb $[12,13]$ found that they possess an identical or very similar isoenzyme structure. A contrasting pattern of divergence was found in plants where speciation is thought to have taken place by a gradual geographic mode. For example, S. Warwick and L. Gottlieb [34] showed that isoenzyme divergence paralleled the degree of divergence in morphology and ecology. These findings mean: the more two taxa diverge in their evolutionary history, the more differences accumulate on a molecular level, resulting in a gradually decreasing homology between their isoenzyme structure [6]. Generally speaking, genetic divergence reflects evolutionary distance between the taxa. Second, similarity of isoenzyme structure implies a common origin and progenitors. When considering a group of related taxa, it is reasonable to assume that each taxon's genome is shared partly by the rest ones. Such groups possess a common ancestral gene pool from which the separate lines (taxa) have originated. One should expect that the genome of more ancient "old" taxa will demonstrate a greater divergence from the common gene pool compared to the more recent "new" taxa within the group.

Bearing in mind the above discussed topic, an attempt will be made to analyze the evolutionary history of the studied group. Using morphological, cytological, ecological and paleobotanical methods, N. Tsvelev [30] proposed a hypothesis about evolution of genus Festuca. Type subgenus Festuca is supposed to have polytopic and paraphyletic origin connected with the Alps' stage of orogenesis. Its prototypes were growing in open high mountains habitats. The main trends of evolution were xeromorphogenesis and cryomorphogenesis. The high mountains' species $F$. picturata is closely related to $F$. rubra. It is considered as an ecologic and geographic race of Alps' $F$. violacea and it is treated as its subspecies in some floras. The Carpathian and Balkan's species F. amethystina is also connected with Alps' orogenesis and it is considered as a transition to more xeromorphic species of Festuca.

It should be mentioned that the degree of integration of vegetative shoots' sheaths (Tabl. 1) has not only diagnostic value but is an indication for the relationships among narrow-leaved fescues. The group of F. rubra s.l. is more primitive compared to $F$. ovina s.l. and has sheaths closed nearly to the mouth while the sheaths of species of section Festuca are closed to the base [4]. Festuca amethystina occupies intermediate position as its sheaths are closed for $1 / 3-1 / 2$ of their length. This character indicates for its specific position within section Aulaxyper and isolates it from the rest taxa of the group. Our results confirmed its peculiar position within section Aulaxyper.

Festuca heterophylla has unique morphological trait (ovary hairy at apex) which is specific for the ancient species of genus Festuca. This character differentiates it from the rest taxa of the group. But $F$. heterophylla has a number of highly-specialized characters: transition to intravaginal reproduction, reduction of veins number of vegetative shoots, reduction of ribs'number on leaves, width reduction of vegetative leaves to $0.3-0.5 \mathrm{~mm}$ in diameter. Such combination of traits is quite unique and confirms the peculiar position of $F$. heterophylla within genus Festuca.

In general, molecular data conform to the above stated hypothesis. In the light of the results, one can suppose that $F$. heterophylla is an ancient species because its genome diverged substantially from the common gene pool. On the contrary, the closely related to $F$. rubra polyploids, namely $F$. nigrescens and $F$. picturata should be considered as more recent "new" species. Festuca amethystina showed the greatest divergence and should be considered also as an ancient species. 
Finally, the molecular data corresponded to the main points of the proposed hypothesis. The more ancient species $F$. heterophylla and $F$. amethystina demonstrated the greatest divergence on molecular level. Their divergence reflected the evolutionary time which had elapsed since the formation of the more advanced polyploids.

\section{REFERENCES}

1. Aiken S., Consaul L., Davis J., Manos P. Systematic inferences from variation in isoenzyme profiles of arctic and alpine cespitose Festuca (Poaceae) // Amer. J. Bot. 1993. Vol. 80. P. 76-82.

2. Aiken S., Spidle A., May B. Allozyme and morphological observations on Festuca hyperborea compared with F. baffinensis and F. brachyphylla (Poaceae) from Canadian Arctic // Nord. J. Bot. 1994. Vol. 14. P. 137-143.

3. Aiken S., Lefkovitch L. Festuca edlundinae (Poaceae), a high Arctic, new species compared enzymatically and morphologically with similar Festuca species // Syst. Bot. 1995. Vol. 20. P. 374-392.

4. Alexeev E. B. The significance of the degree of integration of leaf vagina of vegetative shoots for taxonomy Festuca ovina L. s.l. group // Vestnik Moskovskogo Universiteta. 1972. N 5. P. 48-51. (In Russian).

5. Brown A., Munday J. Population genetic structure and optimal sampling of land races of barley form Iran // Genetica. 1982. VoL. 58. P. 85-96.

6. Crawford D. Phylogenetic and systematic inferences from electrophoretic studies. In: Isoenzymes in plants genetics and breeding (A) Amsterdam: Elsevier, 1983. P. 257-287.

7. Davis B. Disc electrophoresis. I. Method and application to human serum proteins // Ann. N. Y. Acad. Sci. 1964. Vol. 121. P. 404-427.

8. Figueiras D., Gonsales-Jaen M., Salinas J., Benito S. Association of isozymes with a reciprocal translocation in cultivated rye (Secale cereale) // Genetics. 1984. Vol. 109. P. 177-193.

9. Foggi B., Rossi G. A survey of the genus Festuca L. (Poaceae) in Italy. I. The species of the summit flora in the Tuscan-Emilian Apennines and Apuan Alps // Willdenowia. 1996. Vol. 26. P. 1-33.

10. Foggi B., Rossi G., Signorini M. A. The Festuca violacea aggregate in the Alps and Apennines (Central Southern Europe) // Can. J. Bot. 1999. Vol. 77. P. 989-1013.

11. Fuente de la V., Ferrero L.M., Ortuñez E. Chromosome counts in the genus Festuca section Festuca (Poaceae) in the Iberian Peninsula // Bot. J. Linn. Soc. 2001. Vol. 137. P. 385-398.

12. Gottlieb L. Genetic differentiation, sympatric speciation and origin of diploid species of Staephanomeria // Amer. J. Bot. 1973a. Vol. 60. P. 545-555.

13. Gottlieb L. Genetic confirmation of the origin of Clarkia lingulata // Evolution. 1973b. Vol. 88. P. 244-250.

14. Gottlieb L. Conservation and duplication of isoenzymes in plants // Sci. 1982. Vol. 216. P. 373-380.

15. Guldahl A., Borgen L., Nordal I. Variation in the Festuca brachyphylla (Poaceae) complex in Svalbard, elucidated by chromosome numbers and isozymes // Bot. J. Linn. Soc. 2001. Vol. 137. P. 107-126.

16. Hackel E. Monographia festucarum europearum. T. Fischer, Berlin. 1882.

17. Henderson $N$. Isozymes of isocitric dehydrogenase: subunit structure and intracellular location // J. Exp. Zool. 1965. Vol. 158. P. 263-272.

18. Jaaska $\mathrm{V}$. Aspartatate aminotransferase isoenzymes in the polyploid wheats and their diploid relatives // Biochem. Physiol. Pflanzen. 1976. Vol. 170. P. 159-171. 
19. Livesey V., Norrington-Davies J. Isoenzyme polymorphism in Festuca rubra L. // Euphytica. 1991. Vol. 55. P. 52-79.

20. Markgraf-Dannenberg I. Genus Festuca. In: eds. Tutin T.G., Heywood V.H., Burges N.A., Moore D.M., Valentine D.H., Walters S.M., Webb D.A. Flora europaea. 1980. Vol. 5. London: Cambridge University Press. P. 125-153.

21. Nei M. Genetic distance between populations // Amer. Natur. 1972. VoL. 106. P. 283-292.

22. Perez de la Vega M., Allard D. Mating system and genetic polymorphism in populations of Secale cereale and S. vavilovii // Can. J. Genet. Cytol. 1984. Vol. 26. P. 308-317.

23. Przybylska J., Blixt S., Parzysz H., Zimniak-Przybylska Z. Isoenzyme variation in the genus Pisum. I. Electrophoretic patterns of several enzyme systems // Genet. Pol. 1982. Vol. 23. P. 103-121.

24. Salinas J., Perez de la Vega M., Benito $S$. Identification of hexaploid wheat cultivars based on isoenzyme patterns // J. Sci. Food Agr. 1982. Vol. 33. P. 221-226.

25. Shaw C., Prasad R. Starch gel electrophoresis of enzymes - a compilation of recipes // Biochem. J. 1970. Vol. 4. P. 297-310.

26. Šmarda P. DNA ploidy level variability of some fescues (Festuca subg. Festuca, Poaceae) from central and southern Europe measured in fresh plants and herbarium specimens // Biologia. 2008. Vol. 63. P. 349-367.

27. Šmarda P., Burě̌ P., Horová L. et al. Genome size and GC content evolution of Festuca: ancestral expansion and subsequent reduction // Annals of Botany. 2008. Vol. 101. P. 421-433.

28. Šmarda P., Koci K. Chromosome number variability in Central European members of the Festuca ovina and F. pallens groups (sect. Festuca) // Folia Geobotanica. 2003. Vol. 38. P. 65-95.

29. Tzvelev N. On the taxonomy and phylogeny of genus Festuca L. of U.S.S.R. flora. I. The system of the genus and the main trends of evolution // Botanicheskii Zhurnal. 1971. Vol. 56. P. 1252-1262 (In Russian).

30. Tzvelev N. On the taxonomy and phylogeny of genus Festuca L. of U.S.S.R. flora. II. Evolution of subgenus Festuca // Botanicheskii Zhurnal. 1972. Vol. 57. P. 161-181 (In Russian).

31. Tzvelev N. Zlaki SSSR [Grasses of the U.S.S.R.]. Leningrad: Nauka, 1976. 788 p. (In Russian).

32. Tzvelev N. About some species of fescues (Festuca L., Poaceae) Russia. In: Botany (research): Collection of the scientific works. 2010. Vol. 39. P. 114-130. Institute of Experimental Botany of the NAS of Belarus, Minsk (In Russian).

33. Tveretinova $V$. V. Genus Festuca L. In: Prokudin Yu.N. et al. [eds.] Grasses of Ukraine. Kyiv: Naukova Dumka, 1977. P. 265-320. (In Russian).

34. Warwick S., Gottlieb L. Genetic divergence and geographic speciation in Laja (Compositae) // Evol. 1985. Vol. 39. P. 1236-1241.

35. Yeh F., O'Malley D. Enzyme variations in natural populations of Douglas fir, (Pseudotsuga menziesii (Mirb.) Franco, from British Columbia. 1. Genetic variation in coastal populations // Sylvae Genet. 1980. Vol. 29. P. 83-92.

Стаття: надійшла до редакиії 25.09.18

доопращьована 15.11.18

прийнята до друку 16.11 .18 


\title{
МІНЛИВІСТЬ ІЗОЕНЗИМІВ ТА ГЕНЕТИЧНА СПОРІДНЕНІСТЬ П'ЯТЬОХ ВИДІВ FESTUCA CEPIÏ AULAXYPER DUMORT.
}

\author{
Г. Ангелов ${ }^{1}$, І. Беднарська ${ }^{2}$ \\ ${ }^{1}$ Інститут Біорізноманіття та Вивчення Екосистем \\ Болгарської академії наук \\ вул. акад. Г. Бончева, 23, Софія 1113, Болгарія \\ *e-mail:jorkata_1953@mail.bg \\ ${ }^{2}$ Інститут екології Карпат НАН України \\ вул. Козельницька, 4, Львів 79026, Україна \\ e-mail:ibednarska@ukr.net
}

\begin{abstract}
Незважаючи на значну кількість таксономічних i біосистематичних досліджень роду Festuca L. в Європі, є вкрай мало статей, у яких би обговорювали філогенію та систематику роду Festuca, а також еволюцію їі різних груп. Найбільш важливими серед них є дослідження Цвєльова, який запропонував поділ на три секції у межах типового підроду Festuca: Variae Hack., Aulaxyper Dumort. i Festuca. $€$ багато досліджень щодо видів, які належать до секції Festuca, включаючи хемосистематичні, тоді як видами секції Aulaxyper практично нехтують. 3 цієї причини ми обрали $F$. rubra L., F. nigrescens Lam., F. picturata Pils., F. amethystina L. і F. heterophylla Lam., які належать до останньої. Метою дослідження було вивчення мінливості ізоензимів і відповідна оцінка генетичної спорідненості серед вищезгаданих видів роду Festuca.

Було розглянуто десять природних популяцій із Болгарії. Ізоформи ферментів глутамато-оксалоацетатної трансамінази, малатдегідрогенази, глутаматдегідрогенази, ізоцитратдегідрогенази та 6-фосфоглуконатдегідрогенази були досліджені методом електрофорезу в поліакриламідному гелі. Виходячи зі середніх алельних частот / локусів на таксон, були розраховані значення генетичної ідентичності (I) для парних порівнянь усіх досліджуваних видів.

Група F. rubra s.l. є примітивнішою порівняно з F. ovina s.1. - їхні піхви замкнені практично по всій довжині, тоді як краї піхов видів секції Festuca зрослі тільки при основі. Festuca amethystina посідає проміжне місце, оскільки їі піхви замкнені на 1/3$1 / 2$ довжини. Ця ознака вказує на особливий статус виду в секції Aulaxyper i виділяє його 3-поміж інших таксонів групи. Результати наших біохімічних досліджень повністю підтвердили особливе місце виду в секції Aulaxyper. Festuca heterophylla має водночас як примітивні риси, специфічні для давніх видів роду Festuca, так і численні ознаки високої спеціалізації. Отримані молекулярні дані підтверджують своєрідну позицію F. heterophylla у роді Festuca. На противагу їй, тісно пов'язані з політроїдною F. rubra такі види як F. nigrescens i F. picturata слід розглядати як більш пізні «молоді» види. Festuca amethystina, що показала найбільшу розбіжність 3 іншими, має розглядатись як один із давніх видів.
\end{abstract}

Ключові слова: Festuca, ізоферменти, мінливість, систематичні відносини 